\title{
Exploring how companies' support of tourist attractions affects visiting intentions: The mediating role of perceived authenticity
}

\author{
Alessandro Biraglia \\ Maximilian Gerrath \\ Bryan Usrey \\ University of Leeds, UK
}

\begin{abstract}
As public funding for the restoration of tourist attractions decreases, assistance is often sought from the private sector in the form of corporate social responsibility (CSR). However, research has yet to understand how such CSR activities impact the beneficiary, namely tourist attractions. Thus, extending past CSR literature, we explore whether differing company CSR motivations can influence a tourists' visiting intentions. The results of two experimental studies show low company altruism (e.g. demanding to acquire naming rights of the site), compared to high company altruism (e.g. demanding nothing in return), decreases visiting intentions. Furthermore, we show perceived authenticity of the site mediates this effect. Finally, we find the negative effect of low altruistic CSR is mitigated in the case of no heritage. Based on the results, we show tourist attraction managers should be wary of companies displaying non-altruistic intentions, as such activity may have harmful consequences.
\end{abstract}

Keywords: tourist attractions; authenticity; cultural heritage; altruism; CSR; visiting intentions 


\section{Introduction}

Despite their cultural, historical, and societal importance, an increasing number of tourist attractions are struggling financially (Bonham and Mak 1996; Formica and Kothari 2008; Poria 2007; yu Park 2010), due in part to a decrease in public funding for the conservation and restoration of tourist attractions (du Lac 2013; Poria, Ivanov, and Webster 2014) and the unwillingness of attractions to increase admission charges (Garrod and Fyall 2000). To compensate, tourist attractions have become reliant on alternative funding sources. For instance, individuals are often called upon to donate money (Poria, Ivanov, and Webster 2014), while support from the private sector is often solicited to ease tourist attraction financial constraints (European Investment Bank Institute 2013; United Nations 2010). Such support may be vital to the support and preservation of tourist sites. In particular, heritage tourist attractions, which are subject to natural deterioration and under threat to be demolished (BBC 2017; du Lac 2013).

For example, in a recent development, the National Park Service of the United States has estimated its backlog of restoration activities on historic sites, such as the Jefferson Memorial and Mount Rushmore, would cost $\$ 11.9$ billion (Argust 2016). To cover these restoration costs, the National Park Service has become reliant on alternative funding sources. A proposal has been brought forward to allow corporate donors to attain naming rights of tourist attractions in return for financial support (Ferry 2016; Rein 2016).

However, many are skeptical of this approach. For example, Jeff Ruch, executive director of Public Employees for Environmental Responsibility said, "Every developed area in a park could become a venue for product placement" (Rein 2016). Moreover, the Greek government rejected a one-million euro offer from the brand Gucci to host a fashion show at the Acropolis in Athens, which could have aided the government's restoration efforts. (New 
York Times 2017). However, the Greek Central Archaeological Council stated the "particular cultural character of the Acropolis is inconsistent with this event" (ANA-MPA 2017).

When providing financial support for tourist attractions, and thus engaging in corporate social responsibility (CSR), companies may display different levels of altruistic motivation. For example, the Italian fashion company Tod's demonstrated high altruism by agreeing to restore the Colosseum without demanding anything in return (BBC 2011). American Express, however, sought promotional rights when the company agreed to contribute to the restoration of the Statue of Liberty (Gottlieb 1986). Finally, the ticketing agency Eventim renamed the Hammersmith Apollo (now Eventim Apollo) in London, following their involvement in the restoration, thus pursuing more strategic rather than altruistic goals (Nolan 2013).

The degree to which a company displays altruistic motivations in their CSR activities can have an impact on an individual's subsequent visiting intentions. Past literature has shown when a company displays a high level of altruism, individuals have a positive evaluation of the CSR activity (Sen and Bhattacharya 2001). In contrast, those acted out of mere strategic interest are perceived in a more negative manner, which could harm the company (BeckerOlsen, Cudmore, and Hill 2006; Ellen, Webb, and Moh 2006; Vlachos et al. 2009). For instance, in their examination of company CSR, Vlachos, et al. (2009) show perceived egoistic (i.e. CSR conducted based on exploitation motives) and strategic (i.e. CSR conducted based on business motives) CSR activities had a negative impact on consumer trust, patronage intentions, and positive recommendations. In addition, this unfavorable reaction may also affect the beneficiary of the CSR activity, in this case a tourist attraction. Hence, managers of tourist attractions are faced with a question: should they cooperate with a company to reduce their financial struggles or would this compromise the authenticity and visiting intentions for their tourist attractions? 
Thus, the objective of this research is threefold. First, this study examines the effects of (non)altruistic CSR activities on the visiting intentions of tourist attractions. Scholars have routinely examined the impact of CSR from the donor perspective (e.g. a tourism company) and the related reputation and performance outcomes (Aguinis and Glavas 2012; Luo and Bhattacharya 2006; Nicolau 2008; Servaes and Tamayo 2013). In contrast, in this paper we contribute by examining the effect of CSR on the beneficiary, in this case a tourist attraction. External funding sources have been shown to be a vital source in maintaining tourist attractions (Formica and Kothari 2008; Garrod and Fyall 2000). However, the impact of such activities has yet to be uncovered. Second, we contribute to prior literature in the fields of tourism research and CSR by introducing perceived authenticity as a mediating mechanism affecting the relationship between a company's altruistic motivations and visiting intentions. Finally, we examine the role of heritage to determine whether this effect still holds in the case of attractions with no heritage. After a review of the relevant literature and a discussion of the results of two experimental studies, we provide practical implications for managers of tourist attractions. 


\section{Literature review}

An individual's desire to visit tourist attractions can vary. A visitor may wish to take part in a recreational activity or learn about history (Poria, Butler, and Airey 2004). Furthermore, one may feel a personal connection to the heritage of the site (Bonn et al. 2007; Caton and Santos 2007; Poria, Biran, and Reichel 2009). For example, Biran, Poria and Oren (2011) show individuals' visiting intentions to "dark tourism" heritage attractions may be motivated by the personal meaning associated with the site. Due to the personal nature in which an individual views heritage, the sites can garner a high level of interest among the public, and heritage itself can be used as a marketing tool to attract new visitors (Palmer 1999; Wong 2015; Zeppel and Hall 1991). Therefore, a high level of support exists for the conservation of these sites in the public opinion (Bennett et al. 2011). However, the availability of the financial resources required is limited and people may not support the reallocation of public expenditure from other domains into the support of heritage conservation (Bennett et al. 2011; de Rojas and Camerero 2008; Poria, Reichel, and Cohen 2011).

Thus, managers of tourist attractions in need of restoration encounter significant financial pressure (Formica and Kothari 2008; Garrod and Fyall 2000). This situation is exacerbated by the reluctance of managers to increase the admission costs (Leask, Fyall, and Garrod 2002). Routinely, tourist attractions gather money for restoration purposes by enlisting financial support from third-party private sources such as companies (European Investment Bank Institute 2013; Garrod and Fyall 2000). This solution not only helps managers maintain the tourist attraction, but also meets companies' increasing demands from external stakeholders to engage in CSR initiatives (Du, Bhattacharya, and Sen 2010; Sen and Bhattacharya 2001). 


\subsection{Company's motivations to engage in CSR activities and the role of altruism}

Research on CSR in the field of tourism has mainly focused on outcomes of CSR activities (e.g., environmental programs) run by tourism-related businesses (Casado-Díaz et al. 2014; Fraj, Matute, and Melero 2015; Goncalves, Robinot, and Michel 2016; Nicolau 2008; Su, Wang, and Wen 2013; Whitfield and Dioko 2012). Furthermore, scholars discussed CSR activities run by heritage sites and how they affect their local communities and the environment (Edwards 2007; Erkus-Ozturk and Eraydin 2010; Wells et al 2016). Despite that acknowledgment that the conservation of heritage sites is one aspect of CSR (Sheldon and Park 2011), few researchers have examined the outcomes of altruistic CSR motives for the actual beneficiary of CSR activities (e.g., tourist attractions; Pracejus and Olsen 2004). The motivations of companies engaging in CSR activities may vary (Vaaland, Heide, and Grønhaug 2008). For instance, companies may have philanthropic motivations to engage in CSR activities and will act purely altruistically. Altruism is defined as an "action carried out with the intent to benefit others without the desire to receive benefit from others in return" (Romer, Gruder, and, Lizzadro 1986). However, Avolio and Locke (2002) point out altruism does not always involve pure self-sacrifice. Individuals, as well as companies, may exhibit different levels of altruism, determined by their willingness to help and their expectancy of a return. Hence, a company may look at a CSR activity as a long-term investment in the performance of their own organization (Varadarajan and Menon 1988). Prior literature identified several types of CSR classified by their altruistic motives, distinguishing altruistic goals and strategic goals (Lantos 2002; Peloza and Shang 2011). For the purpose of this research, we define low company altruism as a case in which a company agrees to provide support while demanding something in return from the campaign (e.g., the rebranding of the 
monument in return for financial support; Lantos 2002; Németh and Schmidt 2011; Romer, Gruder, and, Lizzadro 1986). In contrast, we define high company altruism as a case in which a company supports a cause without demanding anything in return.

Prior research has demonstrated a company's' CSR activities are evaluated by individuals based on their level of altruism. Specifically, CSR activities driven by values rather than egoistic motivations have been shown to enhance purchase intentions for products (Ellen, Webb, and Moh 2006), while also increasing trust, patronage, and recommendation intentions in the service domain (Vlachos et al. 2009). In contrast, egoistic CSR motivations have been shown to generate negative thoughts and attributions in the mind of consumers in comparison to social motivated CSR activities. Companies may suffer from firm-serving (and thus less altruistic) CSR activities, especially if those activities are falsely communicated as publicserving (Forehand and Grier 2003). Thus, it may be argued attitudes towards companies and their CSR campaigns will degrade if consumers perceive low altruistic motivation (BeckerOlsen, Cudmore, and Hill 2006; Ellen, Webb, and Moh 2006; Groza, Pronschinske and Walker 2011; Lantos 2002). Furthermore, additional factors such as cause fit, company trust, communication strategies, or reputation may mitigate or reverse the positive direct effect of companies' altruism levels on firm-level outcomes of CSR activities (e.g. purchase intentions; Forehand and Grier 2003; Lafferty 2007; Lii and Lee 2012; Rifon et al. 2004; Sen and Bhattacharya 2001; Sohn, Han and Lee 2012; Vlachos et al. 2009).

In addition, altruism has been shown to be positively associated with perceived fairness (Tan and Bolle 2006). In particular, when a firm performs a supposedly altruistic act (e.g. the financial support of a tourist attraction), while simultaneously demanding much in return (e.g. the rebranding of the attraction), consumers may view this as unfair. As fairness refers to perceptions of inequality, consumers may perceive a CSR activity as unfair and unbalanced if it favors the company (Schmidt and Sommerville 2011; Tan and Bolle 2006). This perception 
of unfairness may generate negative associations related to the tourist attraction as a whole, degrading visiting intentions. Sautter and Leisen (1999) found external funding might be met with resistance, due to the personal connection with the heritage site (Bonn et al. 2007; Caton and Santos 2007; Poria, Biran, and Reichel 2009; Poria, Reichel, and Biran 2006). This may be particularly true if a non-altruistic company demands to use the site for marketing activities. Calver and Page (2013) state visitors to heritage sites may not look for diverse entertainment, but rather want to focus on the core historical component of the site. Therefore, visiting intentions of potential tourists may suffer from non-altruistic company involvement.

Hence, we hypothesize that:

H1: The higher the altruistic motivation of a company to engage in a restoration of a tourist attraction, the higher the visiting intentions for the site.

\subsection{The mediating role of authenticity}

Despite the financial benefits associated with external funding sources, the involvement of a company in a restoration may lead to a detraction from the overall authentic heritage of the tourist attraction (Liang et al. 2014). Individuals and communities can be skeptical about these private interventions as they may believe the attraction would lose its authentic aspect (MacDonald 2011).

Authenticity denotes reality, genuineness, originality, conformance to expectations, as well as the extent to which something resembles the original (Sedmak and Mihalič 2008; Trilling 2009; Wong 2015). It can be communicated through references to the origins and history of a 
site, highlighting the elements contributing the most to defining a certain object to a set time and space. Scholars in tourism have identified authenticity as one of the key elements visitors evaluate in a site, determining the perceived quality, the level of satisfaction of their experiences and may lead to higher intentions to visit the sites (Castéran and Roederer 2013; Kolar and Zabkar 2010; Ram, Björk, and Weidenfeld 2016; Wang 1999).

To determine whether a tourist attraction is authentic engenders at least two elements: the nature of the object itself (e.g., its real age) and the perception the beholder has of the object, which may vary from tourist to tourist through a series of cues (Chhabra 2005; Cohen 1979; Cohen and Cohen 2012; Reisinger and Steiner 2006).

Postrel (2003) argues an object is contextualized in a set of given space and time that establishes specific landmarks to its authenticity. Individuals may use these cues (often provided by authorities like museum curators or governmental organizations) to establish whether something is authentic. Tourists also construct their perceptions of authenticity based on their expectations and stereotypes about how the site should look in comparison to reality (Bruner 1994; MacCannell 1973). Hence, the restoration procedures are usually aimed at maintaining the original aspect of a site to minimize the negative difference between the visitors' expectations and their experiences (Kolar and Zabkar 2010; Wang 1999). Wang (1999) divides authenticity into three main categories: objective authenticity, which involves the verification of the original objects (usually based on expert evaluations or certified documents) and tourist attractions; constructed authenticity, which relates to the attributions individuals make of an object or an attraction (based on their expectations and their ideas of authenticity); and finally existential authenticity, which encompasses the feeling of connection individuals have with their inner self and other people by visiting an attraction or witnessing a performance. As we are interested in exploring how individuals perceive and 
contrast the authenticity of a tourist attraction after a company's involvement, we employ constructed authenticity.

When a company engages in the restoration of a tourist attraction, individuals may suspect this initiative to be driven more by strategic motivations rather than by altruism or generosity (Rosenau 2000). This effect is particularly relevant in situations where the company acts out of strategic and non-altruistic motives (e.g., the rebranding of the Hammersmith Apollo as the Eventim Apollo in London). As a result, tourists may perceive the authenticity of the attraction to be jeopardized in tangible (e.g., the name change) or intangible aspects (e.g., lack of the once-felt atmosphere; Gilmore and Pine 2007). In contrast, some individuals may also see an agreement to get publicity out of investments as a form of reciprocity and evaluate it as not particularly harmful (Murstein, Cerreto, and MacDonald 1977), provided that the involvement of a company does not jeopardize the authentic aspect of the site irreversibly. In other words, the transformation of either the physical or the atmospheric aspects of an attraction due to company involvement can induce a sense of lost authenticity that in turn may undermine the intention to visit the attraction. Since perceived authenticity plays such important role in determining individuals' visiting intentions, we hypothesize that:

H2: Perceived authenticity of a tourist attraction mediates the relationship between altruistic motivations of a company and visiting intentions.

\subsection{The impact of company involvement in the restoration of heritage and non-heritage tourist attractions}

Research related to heritage tourist attractions has become one of the main fields of study in tourism. Despite the popularity of this stream of research, Poria, Reichel and Biran (2006) 
point out little research focuses on how tourists perceive heritage attractions and what they expect from them (Poria, Butler, and Airey 2004). Our research intends to close this gap by investigating how a company's financial support may affect the visiting intention of both heritage and non-heritage tourist attractions.

Most definitions for the term cultural heritage in use today originated at conventions of the United Nations Educational, Scientific and Cultural Organization (UNESCO) and International Council on Monuments and Sites (ICOMOS) in the 1970s (Ahmad 2006). Although no standardized worldwide definition of heritage exists, heritage typically entails tangible (e.g. monuments or buildings), intangible (e.g. traditions or knowledge) and environmental (e.g. landscapes surrounding the actual monument) aspects (Ahmad 2006; Daugstad and Kirchengast 2013). While the latter taps more into the natural aspect of heritage (e.g. plants, and the ecosystem of a specific area), our research focuses on the cultural aspects of heritage, which is based on the desire to discover the past through a fulfilling cultural experience (Prideaux and Kininmont 1999; Zeppel and Hall 1991) together with individuals' willingness to learn and educate themselves and strengthen their personal connection to the site (Poria, Biran, and Reichel 2009).

Hence, tourist attractions may or may not possess cultural heritage. On the one hand, heritage tourist attractions may feature buildings in need of restoration with a long lasting tradition and history significant to society. On the other hand, non-heritage tourist attractions offer education value to tourists (e.g. a new museum), but have not yet accumulated tradition, reputation, or other forms of intangible heritage.

Being perceived as authentic is therefore particularly relevant for heritage sites as it guarantees the link with past events, creating an enduring aura around the site itself, reassuring visitors of the genuineness of their experience (Henderson, Edwards, and Molleda 2010; Kidd 2011; Ram, Björk, and Weidenfeld 2016; Rickly-Boyd 2012). The restoration of 
a heritage site tries to maintain this link with the past, even if the process often involves an alteration of its aspect, by implementing, for example, modern materials that resemble the originals. Assessing the exact similarity between original and restored objects requires a certain level of knowledge (Ram, Björk, and Weidenfeld 2016; Wang 1999) that may come from previous direct or indirect experience (e.g., having seen the original object or site or having heard about it from somebody else). However, it is usually difficult for individuals to make this assessment. Hence, to construct their perception of authenticity of the attractions, tourists may rely on meanings, memories, and expectations developed through an individual's cultural background or previous experience (Bennett et al. 2011; Biran, Poria, and Oren 2011; Poria, Biran, and Reichel 2009). Hall and McArthur (1993) argue a visitor's experience is a fundamental aspect to consider when managing heritage sites. As previously mentioned, visitors are not only interested in seeing authentic artefacts and places (Moscardo 1996), but also to fulfilling the desire to learn and be educated through their visit (Falk and Dierking 2016).

As previously discussed, the participation of a company in this operation may generate a negative perception of the result, especially when the initiative of the company had no altruistic intent. This effect is particularly relevant for heritage tourist attractions, as the nonaltruistic intervention may dilute the educational and collective scope of the attraction. However, this may not be the case for non-heritage tourist attractions as these elements of connection to individual and collective identities are not yet part of the attraction itself. Therefore, we hypothesize that:

H3: The mediating effect of authenticity on the relationship between the altruistic motivations of a company and visiting intentions is higher in the case of heritage rather than non-heritage tourist attractions. 


\section{Methodology and Overview of Studies}

As this research aims to examine the impact of CSR activities on visiting intentions, taking into account the mediating variable of authenticity and the moderator of heritage, we selected an experimental approach to allow for the manipulation of such activities by firms. An experimental design is the primary method for exploring causal claims, as it allows for the testing of a direct causal effect of the selected independent variable on the dependent variable, while maintaining control of other potential variables that may interfere in the relationship (Tabachnik and Fidell 2007). Furthermore, experimental research has been employed in past tourism literature (e.g. Book, Tanford, and Chen 2016; Ert and Fleischer 2016; Jun and Holland 2012; Kim, et al. 2016; Nath, Devlin, and Reid 2016; Tanford and Montgomery 2015; Zhang, Wu, and Mattila 2016). Moreover, scholars have called for a deeper understanding of cause-effect relationships in tourism research (Dolnicar and Ring 2014). Therefore, we implement this methodology to test our hypotheses. We designed two experiments for data collection. In the first study, the authors examine the main effect of company altruistic motivations on visiting intentions, testing also the mediating variable of perceived authenticity. In Study 2, we examine the moderating effect of heritage of a tourist attraction on the aforementioned mediation though a moderated mediation test (Hayes 2013). In addition, to enhance generalizability, our predictions are tested with two different tourist attractions: a national park (Study 1) and a museum (Study 2).

To recruit respondents, we used the crowdsourcing platform Amazon Mechanical Turk (MTurk). Scholars have found the platform suitable for experimental research, offering larger and more diverse sample pools compared to typical universities and online samples (Buhrmester, Kwang, and Gosling 2011; Mason and Suri 2012). Moreover, the quality of the data collected has been found to be as reliable as other data collection methods (Buhrmester, 
Kwang, and Gosling 2011; Kim and Fesenmaier 2017; Paolacci, Chandler, and Ipeirotis 2010). 


\section{Study 1}

Using a between-subject experimental design, Study 1 tested the relationship between different levels of altruism regarding a company's motivation to engage in the restoration of a tourist attraction, perceived authenticity of the site, and visiting intentions of tourists.

\subsection{Participants, Procedure, and Measures}

To test $\mathrm{H} 1$ and $\mathrm{H} 2$, data was collected from 173 American respondents (51.4\% female, $\mathrm{M}_{\text {age }}$ $=39.5$ years old) on MTURK.

Three different fictitious newspaper articles about the restoration of a heritage tourist attraction were designed as stimuli to replicate the reports commonly found in newspapers. Each article followed the same structure and introduced a tourist attraction requiring restoration and the company willing to provide financial support. The tourist attraction used in all three conditions of Study 1 was Mount Rushmore in the US, due to its popularity, heritage (i.e. included in the U.S. National Register of Historic Places), and national awareness (National Park Service 2014). The company introduced in each of the stimuli remained unnamed to avoid possible confounding effects. Each condition had the aim to manipulate three different levels of altruism of the company (i.e., low, moderate, and high altruism). In particular, the high altruism condition read that the "firm agreed to cover the cost of a donation, without the intention to use the restoration for commercial or merchandising purposes." In the moderate altruism condition "the firm agreed to cover the cost of a donation, with the agreement to use the site's image as part of their advertising campaigns during the entire period of the restoration and to engage in commercial activities on the National Park's site." Finally, in the low altruism condition, participants read that the 
"firm agreed to cover the cost of a donation, with the agreement to use the site's image as part of their advertising campaigns during the entire period of the restoration and to engage in commercial activities on the National Park's site. Moreover, the company will acquire the naming rights in order to change the official name of the national park to Mount RushmoreBRANDNAME National Park." For the experiment, respondents were randomly assigned to one of the three conditions mentioned above.

For Study 1, participants indicated their visiting intentions on a two-item, seven-point bipolar scale based on Ng, Lee, and Soutar's (2007) measurement (e.g., "not at all intended/very much intended", "definitely not going to visit/definitely going to visit"; $r=.893)$. This intentions measurement method has been commonly employed in past experimental tourism research (e.g. Book, Tanford, and Chen 2016; Dedeke 2016; Sparks and Browning 2011; Sparks, Perkins, and Buckley 2013; Tanford and Montgomery 2015). Then, participants rated the perceived authenticity of the tourist attraction on a six-item seven-point Likert scale adapted from Morhart et al. (2015) and Napoli et al. (2014) (e.g., "After the restoration works, Mount Rushmore will retain its authenticity", "The restoration works will maintain Mount Rushmore's real characteristics"; $\alpha=.899)$. We used a four-item seven-point bipolar scale to measure perceived altruism of the company (e.g., "bad/good, "selfish/altruistic", "greedy/generous", "acting out of a commercial interest/acting out of the interest of the community"; $\alpha=.961)$. Finally, the fairness of the deal was measured using a two-item seven-point Likert scale (e.g., "I think the deal between the government and the company is a fair deal"; $r=.859$ ). Finally, we collected demographic data (e.g., age, gender). A pre-test $(\mathrm{N}=60)$ showed the three conditions differed in terms of altruistic motives of the company $(\mathrm{F}(2,57)=49.132, \mathrm{p}<.001)$. The results of the pre-test were replicated in Study 1 $(\mathrm{F}(2,170)=72.840, \mathrm{p}<.001)$. A Tukey HSD post-hoc test revealed participants evaluated the high altruism condition as being significantly more fair $(\mathrm{M}=5.86, \mathrm{SD}=1.01)$ than the 
moderate $(M=5.19, S D=1.37)$ and the low altruism condition $(M=3.03, S D=1.50)$. Manipulation checks revealed the respondents identified different levels of company altruism $(\mathrm{F}(2,170)=89.820, \mathrm{p}<.001)$. The post-hoc test showed the manipulations correctly predicted the perceptions regarding the altruism of the company (Low altruism condition: $\mathrm{M}$ $=2.79, \mathrm{SD}=1.40 ;$ Moderate altruism condition: $\mathrm{M}=4.57, \mathrm{SD}=1.41 ;$ High altruism condition: $\mathrm{M}=6.05, \mathrm{SD}=1.07)$.

\subsection{Results}

Descriptive analyses do not present any issues with regard to the demographic characteristics of the sample, with subjects homogeneously distributed across groups in relation to their gender $(\mathrm{F}(2,170)=.897 ; \mathrm{p}=.41)$ and age $\left(\chi^{2}=1.294, \mathrm{p}=.52\right)$.

As in the pre-test, two one-way ANOVAs revealed a significant difference in the ratings of perceived fairness $(\mathrm{F}(2,170)=72.840, \mathrm{p}<.001)$ and perceived altruism $(\mathrm{F}(2,170)=$ $85.143, \mathrm{p}<.001)$ between the manipulated levels of company altruism.

To examine H1, we conducted a one-way analysis of variance (ANOVA) to test for significant differences in visiting intentions between the three levels of altruism. Results showed a significant main effect between the low, moderate, and high altruism condition ( $\mathrm{F}$ $(2,170)=9.916, \mathrm{p}<.001)$. Post-hoc test results indicated intentions to visit the site significantly differed between the low and high altruism conditions. However, a significant difference was not found between the moderate $(\mathrm{M}=4.89, \mathrm{SD}=1.40)$ and high altruism $(\mathrm{M}$ $=4.82, \mathrm{SD}=1.32$ ) conditions (figure 1). In conclusion, hypothesis H1 was supported. 
Before examining $\mathrm{H} 2$, we conducted a one-way ANOVA to check whether the three levels of altruism generated differences in the perceptions of the tourist attraction's authenticity. The results showed a significant difference between the three conditions in relation to site authenticity perceptions $(\mathrm{F}(2,170)=50.049, \mathrm{p}<.001)$. Again, the post-hoc test showed no significant difference between the high altruism $(\mathrm{M}=5.87, \mathrm{SD}=.85)$ and the moderate altruism $(\mathrm{M}=5.50, \mathrm{SD}=1.03)$ condition. Hence, tourists' perception of the authenticity of a tourist attraction mainly suffered in the low altruism condition (i.e., the case of rebranding the site). The results suggest the authentic nature of a monument may be jeopardized if a private investor asks to rebrand the site in return, while more altruistic CSR approaches do not alter assessments of authenticity.

Finally, to test $\mathrm{H} 2$ - namely whether authenticity mediates the relationship between company altruism and visiting intentions - we used PROCESS model 4 (Hayes 2013; Preacher and Hayes 2008). First, we analyzed each component of the suggested mediation model through a series of multiple regressions. Altruism was found to be positively associated with visiting intentions $(\beta=.504, \mathrm{t}=3.64, \mathrm{p}=.001)$. Equally, altruism was positively associated with the proposed mediator, perceived authenticity $(\mathrm{a}$ path $=.958, \mathrm{t}=9.13, \mathrm{p}=.001)$. Finally, authenticity was found to be positively associated with visiting intentions ( $\mathrm{b}$ path $=.524, \mathrm{t}=$ $5.65, \mathrm{p}=.001)$. Hence, we conducted a bootstrapping analysis at a confidence interval of 95\% and with 5000 bootstrapping resamples. As hypothesized, the analysis showed a significant mediating effect of authenticity ( $\mathrm{ab}$ path $=.51, \mathrm{CI}=.2740$ to .7549$)$. Furthermore, the direct effect of altruism on visiting intentions was non-significant when controlling for authenticity, which suggested a full mediation (figure $2 ; c^{\prime}$ path $=.002, t=0.126, p=.99$ ). The results indicated visiting intentions were influenced by how altruistically the company acted. However, the effect held only when the authenticity of the monument was considered 
to be preserved and not jeopardized by the company's intervention. Hence, H2 was supported.

\section{-INSERT FIGURE 2 ABOUT HERE-}

\subsection{Discussion}

As hypothesized, higher levels of companies' altruistic motivations were positively associated with visiting intentions. Interestingly, individuals' intentions to visit did not differ between moderate and high company altruism. In addition, individuals evaluated the authenticity of the tourist attraction to be higher in the high altruism condition than in the other two. This effect led to an increase in visiting intentions, supporting the hypothesized mediation model.

Our findings showed tourists generally welcome the philanthropic involvement of a company and the authenticity of a tourist attraction did not suffer from the mere involvement of a company. However, the altruistic motives, or lack thereof, from the company were important predictors of authenticity and visiting intentions. 


\section{Study 2}

While Study 1 focused on the impact of altruistic CSR activities on heritage sites, Study 2 explored whether those effects still persist if companies behave (non-)altruistically in a nonheritage setting. Hence, the moderating role of heritage was examined as a possible moderator between company altruism and perceived authenticity. This allowed for a deeper examination of the conditions in which individuals respond more positively to company involvement in the restoration of tourist attractions. We assumed when the company is involved with a heritage site, the impact of the company's altruism will be magnified compared to a tourist attraction lacking historical significance.

\subsection{Participants, Procedure, and Measures}

To test H3, we conducted a 2 (low altruism vs. high altruism) x 2 (heritage vs. non-heritage) between-subject design experiment. We collected data from 147 American respondents (51.4\% female, $\mathrm{M}_{\mathrm{age}}=34.6$ years old) on MTurk.

All participants were randomly assigned to read one of four fictitious newspaper articles describing companies engaging in the restoration of a museum. Similar to Study 1, we identified no problems relating to non-homogeneous demographic characteristics across conditions. In the heritage condition, the museum was described as a "museum in New York City, established in 1870, which was subject to minor renovations over its history, [and] now requires major structural renovation". For the purpose of this study, we used the Metropolitan Museum of Art, as it is one of the oldest and most visited museums in the United States (The Art Newspaper 2015). Moreover, it is listed in the National Register of Historic Places (NRHP) of the United States federal government (National Park Service 2017). In the non- 
heritage condition, respondents read about a new museum being constructed in New York City and that "construction of the new museum is scheduled to commence soon." Finally, as in Study 1, altruism was manipulated by either describing the involvement of the private company as a "donation, without the intention to use restoration for commercial or merchandising purposes," or as an "agreement to engage in commercial activities on the Museum's site. Moreover, the company will acquire the naming rights in order to change the official name of the museum to "BRANDNAME Metropolitan Museum of Art." As in Study 1, participants reported their visiting intentions $(r=.902)$. To measure the perceived fairness of the CSR agreement, a three-item seven-point Likert scale was adapted to meet both the construction and restoration contexts of Study 2 (e.g., "the firm demands too much in return for its financial support," "the deal mainly favors the firm;" $\alpha=.878$ ). Similarly, we included the same four-item seven-point Likert scale of the pre-test and Study 1 to measure perceived altruism $(\alpha=.936)$. Finally, authenticity was measured on an adapted six-item, seven-point Likert scale to meet the museum context of Study 2 (e.g. "...the museum will retain its authenticity," "...the museum will lose its real aspect," “...the museum will lose its credibility;" $\alpha=.877)$.

Because our manipulations focus upon the restoration or construction of the museum building, we focus upon the general constructed authenticity of the museum, rather than its collection. We took this decision for two main reasons: First, we wanted to prevent confounds across the manipulations, as the newly built museum would not have any collection to exhibit compared to the one in need for restoration. Second, as Gilmore and Pine (2007) point out, individuals consider collections in a museum as naturally authentic because they have been validated by experts (meeting the definition of objective authenticity). Individuals may instead evaluate the authenticity of museums as edifices (Brida, Disegni, and Scuderi 2014; Gilmore and Pine 2007), and, in this case, their evaluation of authenticity relies 
more on their perception of the building, relating to the constructed authenticity definition we test in this study.

\subsection{Results}

We did not find any significant differences regarding gender $(F(3,143)=.599 ; \mathrm{p}=.62)$ and age $\left(\chi^{2}=.898, p=.83\right)$ across the conditions.

As in the pre-test and Study 1, two one-way ANOVAs revealed a significant difference in the ratings of perceived fairness $(\mathrm{F}(1,145)=75.377, \mathrm{p}<.001)$ and perceived altruism $(\mathrm{F}(1$, $145)=164.161, \mathrm{p}<.001)$ between the manipulated levels of company altruism.

We conducted a two-way ANOVA to examine the effect of company altruism and heritage on perceived authenticity of the tourist attraction. The interaction effect between altruism and heritage was significant $(\mathrm{F}(1,143)=4.157, \mathrm{p}<.05)$. Respondents evaluated the authenticity of the non-heritage $(M=5.73)$ and heritage $(M=5.81)$ sites to be relatively similar in the case of high altruism. However, in the case of low altruism, the non-heritage site was perceived to be more authentic $(M=4.89)$ compared to the heritage site $(M=4.25)$. Finally, company altruism showed to have a statistically significant main effect on the perceived authenticity of the site $(\mathrm{F}(1,143)=45.632, \mathrm{p}<.001)$.

An additional two-way ANOVA examined the interaction of altruism and heritage on visiting intentions. Again, the interaction of altruism and heritage was statistically significant (F (1, $143)=5.929, \mathrm{p}<.05)$. In the case of the heritage site, visiting intentions increased from low $(M=4.08)$ to high altruism $(M=5.24)$ of the company. In contrast, the visiting intentions for the non-heritage site stayed stable in the case of low $(M=4.95)$ and high altruism $(M=4.91$; figure 3). We also observed a significant main effect of altruism in predicting visiting intentions $(\mathrm{F}(1,143)=5.172, \mathrm{p}<.05)$, which provides further support to $\mathrm{H} 1$. 
-INSERT FIGURE 3 ABOUT HERE

We performed a moderated mediation using PROCESS model 8 (Hayes 2013) to further investigate the hypothesized role that heritage has in moderating the relationship of company altruism and perceived authenticity, while testing simultaneously the mediating role of authenticity on visiting intentions found in Study 1 . The model included company altruism as the independent variable, heritage as the moderator, perceived authenticity as mediator, and visiting intentions as a dependent variable (Figure 4). The interaction of the independent variable (altruism) and moderator (heritage) was found to be positively associated with the mediator (perceived authenticity; a3 path $=.724, \mathrm{t}=2.04, \mathrm{p}<.05, \mathrm{CI}=.0221$ to 1.4258 ), while perceived authenticity influenced visiting intentions significantly $(\mathrm{b}$ path $=.341, \mathrm{t}=$ $3.01, \mathrm{p}<.01, \mathrm{CI}=.1174$ to .5648 ). The inclusion of the mediator (authenticity) led to an insignificant direct relationship between the interaction of altruism and heritage on visiting intentions ( $c^{\prime} 3$ path, no heritage $=-.325, \mathrm{CI}=-1.0424$ to $.3919 ; c^{\prime} 3$ path, heritage $=.630, \mathrm{CI}$ $=-.1078$ to 1.3684 ). Following this assessment, we conducted a bootstrapping analysis at a confidence interval of $95 \%$ and with 10,000 bootstrapping resamples.

As hypothesized, the analysis shows a significant mediating effect of authenticity in the relationship between the altruism $\mathrm{x}$ heritage interaction and visiting intentions. The mediation was stronger in the case of heritage (a3b path, heritage $=.533, \mathrm{CI}=.1155$ to 1.0284 ) in comparison to the non-heritage case (a3b path, no heritage $=.286, \mathrm{CI}=.0573$ to .6492 ). Furthermore, a full mediation is supported as the direct effects became insignificant when accounting for the mediator authenticity in both the heritage and the non-heritage condition. The findings suggest authenticity plays a larger role in explaining the relationship between 
altruism and visiting intentions in the case of heritage sites in comparison to non-heritage sites. Hence, H3 was supported.

\section{-INSERT FIGURE 4 ABOUT HERE-}

\subsection{Discussion}

The results from Study 2 confirmed a company's level of altruism has a significant impact upon perception of authenticity of a tourist attraction, which in turn, influenced individuals' visiting intentions. Nevertheless, it was shown that the influence of altruism through authenticity on visiting intentions is determined by the nature of the focal tourist attraction (i.e., heritage vs. non-heritage). If a tourist attraction has no heritage, individuals may still intend to visit even when a company acts non-altruistically (e.g., by rebranding the site). Hence, we conclude tourists may not reject as a whole the idea of companies supporting the restoration or construction of tourist sites in financial need. We identified certain boundary conditions in which tourists may not mind commercial activities as well as the rebranding of a (heritage) tourist attraction. 


\section{Conclusion}

Against the backdrop of increasing financial challenges facing tourist attractions, site managers are faced with a dilemma. By cooperating with companies, they may alleviate the attractions' financial adversity. However, in doing so, the long-term risks, driven by the companies' strategic interests, could be problematic. Therefore, this research aimed to examine how varying degrees of company altruism impact the site's authenticity and visiting intentions.

Notably, this article contributes to prior research in multiple ways. First, we show that CSR activities can have negative outcomes for causes like tourist attractions in need of restoration, especially in the case of low company altruism. In this instance, special benefits are conceded to companies in exchange of financial support (e.g. by granting them the naming rights of the attraction), which may have a jeopardizing effect in the long term as individuals may not intend to visit the site. Second, we show this negative effect on visiting intentions is determined by lowered perceptions of authenticity. Finally, we show low company altruism is especially damaging for the perceived authenticity and, ultimately, visiting intentions of heritage sites. In contrast, non-heritage sites are not strongly affected by strategic motivations of companies to engage in CSR activities related to the site.

\subsection{Implications for theory, practice and policy}

Under a theoretical perspective, our research contributes to the general business and management literature by providing a new angle on CSR. Specifically, this new perspective relates to the effect of different levels of donor altruism and its effect on the beneficiary. This aspect has been often neglected in past literature that has mainly focused on aspects related to 
the beliefs individuals have in relation to the company implementing the CSR activities. Furthermore, this study enriches the tourism literature by investigating a relevant and contemporary issue (i.e. the lack of funding for tourism attractions) and how company altruism, or a lack thereof, may affect how visitors perceive the authenticity of the site. Specifically, the link between altruism and its effect on perceived authenticity has rarely been investigated and, to the best of our knowledge, has not been studied in the tourism context. Furthermore, several important implications for managers can be drawn from our results. Even though funds to restore tourist attractions are scarce, managers may be ill-advised to accept CSR agreements demanding too much from the tourist attractions. While this may improve the financial situation of a tourist attraction in the short-term, it can be damaging in the long-term due to the decreased perceived authenticity of the site and its resulting decrease in visiting intentions of tourists. In particular, it may not be advisable to partner with a company that follows strategic and clearly non-altruistic motives (e.g., when a company is planning to rebrand a tourist attraction). Managers of heritage attractions should be especially careful about allowing companies to change the nature of the site due to non-altruistic reasons.

Our results can also aid policy makers in shaping new initiatives that include private investors and the potential benefits they may receive in return for their involvement. One way to encourage investment may be a tax discount program for companies who donate to tourist attractions in need. This is an experiment that has already started in some countries around the world and could be extended to other locations and for longer periods of time. Based on the results of Study 2, a second alternative is to promote private investment in new tourist attractions. The opening of these new attractions may coincide with the emerging trend in revitalizing neighborhoods in different cities that have been progressively abandoned but are rich in cultural heritage (Ashley 2014). These initiatives could be beneficial not only for the 
tourism industry, but also to the broader economy and welfare of local communities, creating new jobs and places as potential incubators of cultural activities.

\subsection{Limitations and future research}

This research examined its hypotheses in a tourism context. It may be plausible to find similar patterns in other types of CSR agreements (e.g., sponsorship and rebranding of events or sports teams with heritage). Future research may investigate the relationship between altruism and authenticity in different contexts and provide further proof of the reliability, generalizability, and robustness of the relationships we found. Furthermore, our research relied on an American sample and used American tourist attractions in its experimental designs to rule out any underlying confounds like geographical distance. Future research may explore the role of company altruism and perceived authenticity in predicting visiting intention in different cultural contexts. It is feasible that cultures with a higher long-term orientation than the United States, such as Japan, may react differently to low levels of company altruism, together with their perceptions of fairness and morality.

Similarly, scholars may test the impact of company altruism on other aspects of authenticity of tourist attractions, as this study focuses on constructed authenticity of the target museum only. Future research can explore the impact company intervention has on visitors' constructed authenticity of the museum's collection and even the level of existential authenticity while individuals visit an attraction rebranded or used for commercial activities. Future research can look at the impact of altruism in CSR strategies on different types of heritage sites (such as natural heritage), which we did not focus on in this study. Finally, this research adds to the growing body of studies using an experimental approach to establish causal links among phenomena in the field of tourism. In the future, scholars may use 
methodologies (e.g. surveys) that can incorporate additional factors (e.g. other CSR dimensions) that may determine visiting intentions of restored tourist attractions. 


\section{References}

Aguinis, H., and A. Glavas. 2012. "What we know and don't know about corporate social responsibility a review and research agenda." Journal of Management 38 (4):932968.

Ahmad, Y. 2006. "The scope and definitions of heritage: from tangible to intangible." International Journal of Heritage Studies 12 (3):292-300.

ANA-MPA. 2017. “Archaeological body rejects Gucci's proposal for fashion show on Acropolis Hill.” http://www.amna.gr/english/article/17215/Archaeological-bodyrejects-Guccis-proposal-for-fashion-show-on-Acropolis-Hill (accessed February 27, 2017).

Argust, M. 2016. “7 Popular National Park Sites Struggle With Deferred Maintenance.” http://www.pewtrusts.org/en/research-and-analysis/analysis/2016/09/01/7-popularnational-park-sites-struggle-with-deferred-maintenance (accessed February 27, 2017).

Ashley, A. J. 2014. "Negotiating risk in property-based arts economic development: Exploring the innovative but untimely development partnership between the Seattle Art Museum and Washington Mutual." Cities 37: 92-103.

Avolio, B. J., and E. E Locke. 2002. "Contrasting different philosophies of leader motivation: Altruism versus egoism." The Leadership Quarterly 13 (2):169-191.

BBC. 2011. "Rome Colosseum repair to be funded by Tods shoe firm." http://www.bbc.co.uk/news/world-europe-12256813 (accessed May 10, 2016).

BBC. 2017. "Wentworth Castle Gardens to close in funding crisis". http://www.bbc.co.uk/news/uk-england-south-yorkshire-38829507 (accessed February 2, 2017). 
Becker-Olsen, K. L., B. A. Cudmore, and R. P. Hill. 2006. "The impact of perceived corporate social responsibility on consumer behavior." Journal of Business Research 59 (1):46-53.

Bennett, R., F. Kerrigan, D. O'Reilly, and H. McDonald. 2011. "Understanding the antecedents to public interest and engagement with heritage." European Journal of Marketing 45 (5):780-804.

Biran, A., Y. Poria, and G. Oren. 2011. "Sought experiences at (dark) heritage sites.” Annals of Tourism Research 38 (3):820-841.

Bonham, C., and J. Mak. 1996. "Private versus public financing of state destination promotion." Journal of Travel Research 35 (2):3-10.

Bonn, M. A., S. M. Joseph-Mathews, M. Dai, S. Hayes, and J. Cave. 2007. "Heritage/cultural attraction atmospherics: Creating the right environment for the heritage/cultural visitor." Journal of Travel Research 45 (3):345-354.

Book, L.A., S. Tanford, and Y.S. Chen. 2016. "Understanding the Impact of Negative and Positive Traveler Reviews: Social Influence and Price Anchoring Effects.” Journal of Travel Research 55 (8):993-1007.

Brida, J. G., M. Disegna, and R. Scuderi. 2014. "The visitors' perception of authenticity at the museums: Archaeology versus modern art." Current Issues in Tourism 17 (6):518538.

Bruner, E. M. 1994. "Abraham Lincoln as authentic reproduction: A critique of postmodernism." American Anthropologist 96 (2):397-415.

Buhrmester, M., T. Kwang, and S. D. Gosling. 2011. "Amazon's Mechanical Turk a new source of inexpensive, yet high-quality, data?" Perspectives on Psychological Science 6 (1):3-5. 
Calver, S. J., and S. J. Page. 2013. "Enlightened hedonism: Exploring the relationship of service value, visitor knowledge and interest, to visitor enjoyment at heritage attractions." Tourism Management 39:23-36.

Casado-Díaz, A. B., J. L. Nicolau, F. Ruiz-Moreno, and R. Sellers. 2014. "Industry-specific effect of CSR initiatives: Hotels and airlines.” Kybernetes 43(3/4):547-564.

Castéran, H., and C. Roederer. 2013. "Does authenticity really affect behavior? The case of the Strasbourg Christmas Market." Tourism Management 36:153-163.

Caton, K., and C. A. Santos. 2007. "Heritage tourism on Route 66: Deconstructing nostalgia." Journal of Travel Research 45 (4):371-386.

Chhabra, D. 2005. "Defining authenticity and its determinants: Toward an authenticity flow model." Journal of Travel Research 44 (1):64-73.

Cohen, E. 1979. "A phenomenology of tourist experiences." Sociology 13 (2):179-201.

Cohen, E., and S. A. Cohen. 2012. "Current sociological theories and issues in tourism." Annals of Tourism Research 39 (4):2177-2202.

Daugstad, K., and C. Kirchengast. 2013. "Authenticity and the pseudo-backstage of agritourism." Annals of Tourism Research 43:170-191.

De Rojas, C., and C. Camarero. 2008. "Visitors' experience, mood and satisfaction in a heritage context: Evidence from an interpretation center." Tourism Management 29 (3):525-537.

Dedeke, A. 2016. "Travel web-site design: Information task-fit, service quality and purchase intention.” Tourism Management 54:541-554.

Dolnicar, S., and A. Ring. 2014. "Tourism marketing research: past, present and future.” Annals of Tourism Research 47:31-47. 
Du Lac, J.F. 2013. "Historic house museums struggling to survive." https://www.bostonglobe.com/news/nation/2013/01/06/struggling-draw-visitorshistoric-houses-may-face-day-reckoning/dpStIC3aaajDFJ6aMKW9CM/story.html (accessed December 5, 2016).

Edwards, D. 2007. "Corporate social responsibility of large urban museums: the contribution of volunteer programs." Tourism Review International 11 (2):167-174.

Ellen, P. S., D. J. Webb, and L. A. Mohr. 2006. "Building corporate associations: Consumer attributions for corporate socially responsible programs." Journal of the Academy of Marketing Science 34 (2):147-157.

Erkuş-Öztürk, H., and A. Eraydın. 2010. "Environmental governance for sustainable tourism development: Collaborative networks and organisation building in the Antalya tourism region." Tourism Management 31 (1):113-124.

Ert, E., and A. Fleischer. 2016. “Mere Position Effect in Booking Hotels Online.” Journal of Travel Research 55 (3):311-321.

European Investment Bank Institute. 2013. "Funding sources for preserving Cultural Heritage Monuments and Sites." http://www.europanostra.org/UPLOADS/FILS/7ME-2013EIBI-HeritageFundingOverview.pdf (accessed June 3, 2016).

Falk, J. H., and L. D. Dierking. 2016. The museum experience revisited. New York: Routledge.

Ferry, D. 2017. “The Park Service's \$12 Billion Backlog Is No Excuse to Sell Our Public Land.” https://www.outsideonline.com/2158451/whats-really-stake-park-services-12billion-backlog (accessed February 27, 2017).

Forehand, M. R., and S. Grier. 2003. "When is honesty the best policy? The effect of stated company intent on consumer skepticism." Journal of Consumer Psychology 13 (3):349-356. 
Formica, S., and T. H. Kothari. 2008. "Strategic destination planning: Analyzing the future of tourism." Journal of Travel Research 46 (4):355-367.

Fraj, E., J. Matute, and I. Melero. 2015. "Environmental strategies and organizational competitiveness in the hotel industry: The role of learning and innovation as determinants of environmental success." Tourism Management 46:30-42.

Garrod, B., and A. Fyall. 2000. "Managing heritage tourism." Annals of Tourism Research 27 (3):682-708.

Gilmore, J. H., and B. J. Pine. 2007. Authenticity: What consumers really want. Boston: Harvard Business Press.

Goncalves, O., E. Robinot, and H. Michel. 2016. "Does it pay to be green? The case of French ski resorts". Journal of Travel Research. 55(7):889-903.

Gottlieb, M. 1986. "Marketing of status alters nature of fund-raising." http://www.nytimes.com/1986/06/15/nyregion/marketing-of-statue-alters-nature-offund-raising.html?pagewanted=all (accessed June 9, 2016).

Groza, M. D., M. R. Pronschinske, and M. Walker. 2011. "Perceived organizational motives and consumer responses to proactive and reactive CSR." Journal of Business Ethics $102(4): 639-652$.

Hall, C. M., and S. McArthur. 1993. Heritage management in New Zealand and Australia: visitor management, interpretation and marketing: Oxford University Press, USA.

Hayes, A. F. 2013. Introduction to mediation, moderation, and conditional process analysis: A regression-based approach. New York: Guilford Press.

Henderson, A., L. Edwards, and J.-C. Molleda. 2010. "Authenticity and the construct's dimensions in public relations and communication research." Journal of Communication Management 14 (3):223-236. 
Jun, S.H., and S. Holland. 2012. "Information-Processing Strategies: A Focus on Pictorial Informational Roles.” Journal of Travel Research 51 (2):205-218.

Kidd, J. 2011. "Performing the knowing archive: heritage performance and authenticity." International Journal of Heritage Studies 17 (1):22-35.

Kim, J., and D.R. Fesenmaier. 2017. "Sharing Tourism Experiences: The Posttrip Experience.” Journal of Travel Research 56 (1):28-40

Kim, J., P.B. Kim., J.E. Kim, and V.P. Magnini. 2016. “Application of Construal-Level Theory to Promotional Strategies in the Hotel Industry.” Journal of Travel Research 55 (3):340-352.

Kolar, T., and V. Zabkar. 2010. "A consumer-based model of authenticity: An oxymoron or the foundation of cultural heritage marketing?" Tourism Management 31 (5):652664.

Lafferty, B. A. 2007. "The relevance of fit in a cause-brand alliance when consumers evaluate corporate credibility." Journal of Business Research 60 (5):447-453.

Lantos, G. P. 2002. "The ethicality of altruistic corporate social responsibility." Journal of Consumer Marketing 19 (3):205-232.

Leask, A., A. Fyall, and B. Garrod. 2002. "Heritage visitor attractions: Managing revenue in the new millennium." International Journal of Heritage Studies 8 (3):247-265.

Lii, Y.-S., and M. Lee. 2012. "Doing right leads to doing well: When the type of CSR and reputation interact to affect consumer evaluations of the firm." Journal of Business Ethics 105 (1):69-81.

Luo, X., and C. B. Bhattacharya. 2006. "Corporate social responsibility, customer satisfaction, and market value." Journal of Marketing 70 (4):1-18.

MacCannell, D. 1973. "Staged authenticity: Arrangements of social space in tourist settings." American Journal of Sociology:589-603. 
MacDonald, S. 2011. "Leveraging heritage: Public-private, and third-sector partnerships for the conservation of the historic urban environment". Paper presented at the International Council on Monuments and Sites (ICOMOS) 17th General Assembly, Paris, France. $27^{\text {th }}$ November $-02^{\text {nd }}$ December.

Mason, W., and S. Suri. 2012. “Conducting behavioral research on Amazon's Mechanical Turk.” Behavior Research Methods 44 (1):1-23.

Morhart, F., L. Malär, A. Guèvremont, F. Girardin, and B. Grohmann. 2015. "Brand authenticity: An integrative framework and measurement scale." Journal of Consumer Psychology 25 (2):200-218.

Moscardo, G. 1996. "Mindful Visitors: Heritage and Tourism." Annals of Tourism Research 23 (2):376-397.

Murstein, B. I., M. Cerreto, and M. G. MacDonald. 1977. "A theory and investigation of the effect of exchange-orientation on marriage and friendship." Journal of Marriage and the Family 39 (3):543-548.

Napoli, J., S. J. Dickinson, M. B. Beverland, and F. Farrelly. 2014. "Measuring consumerbased brand authenticity." Journal of Business Research 67 (6):1090-1098.

Nath, P., J. Devlin, and V. Reid. 2016. "Expectation Formation in Case of Newer Hotels: The Role of Advertising, Price, and Culture.” Journal of Travel Research 55 (2):261-275.

National Park Service. 2014. "National Register of Historic Places Program." https://www.nps.gov/nr/feature/places/R_A_AD_66000718_03_20_2014.htm (accessed February 12, 2017).

National Park Service. 2016. "Park Statistics." https://www.nps.gov/moru/learn/management/statistics.htm (accessed June 3, 2016). National Park Service. 2017. "National Register of Historic Places Digital Archive." https://npgallery.nps.gov/nrhp/Download/\#simplified (accessed February 27, 2017). 
Németh, J., and S. Schmidt. 2011. "The privatization of public space: modeling and measuring publicness." Environment and Planning B: Planning and Design 38 (1):523.

New York Times. 2017. "Greece Says No to Gucci Fashion Show at Acropolis." https://www.nytimes.com/aponline/2017/02/15/world/europe/ap-eu-greeceacropolis.html (accessed February 27, 2017).

Ng, S. I., J. A. Lee, and G. N. Soutar. 2007. "Tourists' intention to visit a country: The impact of cultural distance." Tourism Management 28 (6):1497-1506.

Nicolau, J. L. 2008. "Corporate Social Responsibility: Worth-Creating ctivities." Annals of Tourism Research 35 (4):990-1006.

Nolan, S. 2013. "Back to its former glory: Hammersmith Apollo opens its doors after a $£ 5$ million refit that has restored original art deco designs.” http://www.dailymail.co.uk/news/article-2414149/Hammersmith-Apollo-opensdoors-5million-refit-restored-art-deco-designs.html (accessed May 8, 2016).

Palmer, C. 1999. "Tourism and the symbols of identity." Tourism Management 20 (3):313321.

Paolacci, G., J. Chandler, and P. G. Ipeirotis. 2010. "Running experiments on amazon mechanical turk." Judgment and Decision Making 5 (5):411-419.

Peloza, J., and J. Shang. 2011. "How can corporate social responsibility activities create value for stakeholders? A systematic review." Journal of the Academy of Marketing Science 39 (1):117-135.

Poria, Y. 2007. "Establishing cooperation between Israel and Poland to save Auschwitz Concentration Camp: globalising the responsibility for the Massacre". International Journal of Tourism Policy 1 (1):45-57. 
Poria, Y., A. Biran, and A. Reichel. 2009. "Visitors' preferences for interpretation at heritage sites." Journal of Travel Research. 48 (1):92-105.

Poria, Y., R. Butler, and D. Airey. 2004. "Links between tourists, heritage, and reasons for visiting heritage sites.” Journal of Travel Research. 43(1):19-28.

Poria, Y., S. Ivanov, and C. Webster. 2014. "Attitudes and willingness to donate towards heritage restoration: an exploratory study about Bulgarian socialist monuments." Journal of Heritage Tourism 9 (1):68-74.

Poria, Y., A. Reichel, and A. Biran. 2006. "Heritage site perceptions and motivations to visit." Journal of Travel Research 44 (3):318-326.

Poria, Y., A. Reichel, and R. Cohen. 2011. "World heritage site-Is it an effective brand name? A case study of a religious heritage site." Journal of Travel Research 50 (5):482-495.

Postrel, V. 2003. The substance of style: How the rise of aesthetic value is remaking culture, commerce, and consciousness: New York: HarperCollins.

Pracejus, J. W., and G. D. Olsen. 2004. "The role of brand/cause fit in the effectiveness of cause-related marketing campaigns." Journal of Business Research 57 (6):635-640.

Preacher, K. J., and A. F. Hayes. 2008. "Asymptotic and resampling strategies for assessing and comparing indirect effects in multiple mediator models." Behavior Research Methods 40 (3):879-891.

Prideaux, B. R., and L.-J. Kininmont. 1999. "Tourism and heritage are not strangers: A study of opportunities for rural heritage museums to maximize tourism visitation." Journal of Travel Research 37 (3):299-303.

Ram, Y., P. Björk, and A. Weidenfeld. 2016. "Authenticity and place attachment of major visitor attractions." Tourism Management 52:110-122. 
Rein, L. 2016. "Yosemite, sponsored by Starbucks? National Parks to start selling some naming rights."

https://www.washingtonpost.com/news/powerpost/wp/2016/05/09/yosemite-nationalpark-brought-to-you-by-starbucks/ (accessed June 3, 2016).

Reisinger, Y., and C. J. Steiner. 2006. "Reconceptualizing object authenticity." Annals of Tourism Research 33 (1):65-86.

Rickly-Boyd, J. M. 2012. "Authenticity \& aura: A Benjaminian approach to tourism." Annals of Tourism Research 39 (1):269-289.

Rifon, N. J., S. M. Choi, C. S. Trimble, and H. Li. 2004. "Congruence effects in sponsorship: The mediating role of sponsor credibility and consumer attributions of sponsor motive." Journal of Advertising 33 (1):30-42.

Romer, D., C. L. Gruder, and T. Lizzadro. 1986. "A person-situation approach to altruistic behavior." Journal of Personality and Social Psychology 51 (5):1001.

Rosenau, P. V. 2000. Public-Private policy partnerships: MIT Press.

Sautter, E. T., and B. Leisen. 1999. "Managing stakeholders a tourism planning model." Annals of Tourism Research 26 (2):312-328.

Schmidt, M. F. H., and J. A. Sommerville. 2011. "Fairness expectations and altruistic sharing in 15-month-old human infants." PloS one 6 (10):e23223.

Sedmak, G., and T. Mihalič. 2008. "Authenticity in mature seaside resorts." Annals of Tourism Research 35 (4):1007-1031.

Sen, S., and C. B. Bhattacharya. 2001. "Does doing good always lead to doing better? Consumer reactions to corporate social responsibility." Journal of Marketing Research 38 (2):225-243. 
Seok Sohn, Y., J. K. Han, and S.-H. Lee. 2012. "Communication strategies for enhancing perceived fit in the CSR sponsorship context." International Journal of Advertising 31 (1):133-146.

Servaes, H., and A. Tamayo. 2013. "The impact of corporate social responsibility on firm value: The role of customer awareness." Management Science 59 (5):1045-1061.

Sparks, B.A., and V. Browning. 2011. "The impact of online reviews on hotel booking intentions and perception of trust.” Tourism Management 32 (6):1310-1323.

Sparks, B.A., H.E. Perkin, and R. Buckley. 2013. "Online travel reviews as persuasive communication: The effects of content type, source, and certification logos on consumer behavior.” Tourism Management 39:1-9.

Su, X., H. Wang, and T. Wen. 2013. "Profit, responsibility, and the moral economy of tourism." Annals of Tourism Research 43:231-250.

Tabachnick, B. G., and L. S. Fidell. 2007. Experimental designs using ANOVA: Thomson/Brooks/Cole.

Tan, J. H., and F. Bolle. 2006. "On the relative strengths of altruism and fairness." Theory and Decision 60 (1):35-67.

Tanford, S, and R. Montgomery. 2015. "The Effects of Social Influence and Cognitive Dissonance on Travel Purchase Decisions.” Journal of Travel Research 54 (5):596610.

The Art Newspaper. 2015. "Visitor Figures 2014." http://www.museus.gov.br/wpcontent/uploads/2015/04/TheArtNewspaper_Ranking2014.pdf (accessed June 3, 2016).

Trilling, L. 2009. Sincerity and authenticity: Harvard University Press.

United Nations. 2010. "Promoting Foreign Investment in Tourism." http://unctad.org/en/Docs/diaepcb200916_en.pdf (accessed June 3, 2016). 
Vaaland, T. I., M. Heide, and K. Grønhaug. 2008. "Corporate social responsibility: Investigating theory and research in the marketing context." European Journal of Marketing 42 (9/10):927-953.

Varadarajan, P. R., and A. Menon. 1988. "Cause-related marketing: A coalignment of marketing strategy and corporate philanthropy." Journal of Marketing 52 (3):58-74.

Vlachos, P. A., A. Tsamakos, A. P. Vrechopoulos, and P. K. Avramidis. 2009. "Corporate social responsibility: Attributions, loyalty, and the mediating role of trust." Journal of the Academy of Marketing Science 37 (2):170-180.

Wang, N. 1999. "Rethinking authenticity in tourism experience." Annals of Tourism Research 26 (2):349-370.

Wells, V. K., D. G. Smith, B. Taheri, D. Manika, and C. McCowlen. 2016. "An exploration of CSR development in heritage tourism." Annals of Tourism Research 58:1-17.

Whitfield, J., and L. A. N. Dioko. 2012. "Measuring and examining the relevance of discretionary corporate social responsibility in tourism: Some preliminary evidence from the UK conference sector." Journal of Travel Research 51 (3):289-302.

Wong, I. A. 2015. "A Multimethod Multilevel Study of Heritage Transmission The Role of Culture on Tourist Interest and Authenticity." Journal of Travel Research 54 (5):672685.

yu Park, H. 2010. "Heritage tourism: Emotional journeys into nationhood." Annals of Tourism Research 37 (1):116-135.

Zhang, L., L. Wu, and A.S. Mattila. 2016. "Online Reviews: The Role of Information Load and Peripheral Factors.” Journal of Travel Research 55 (3):299-310.

Zeppel, H., and C. M. Hall. 1991. "Selling art and history: Cultural heritage and tourism." Journal of Tourism Studies 2 (1):29-45. 
Figure 1 - Effect of firm altruism on visiting intentions (Study 1)

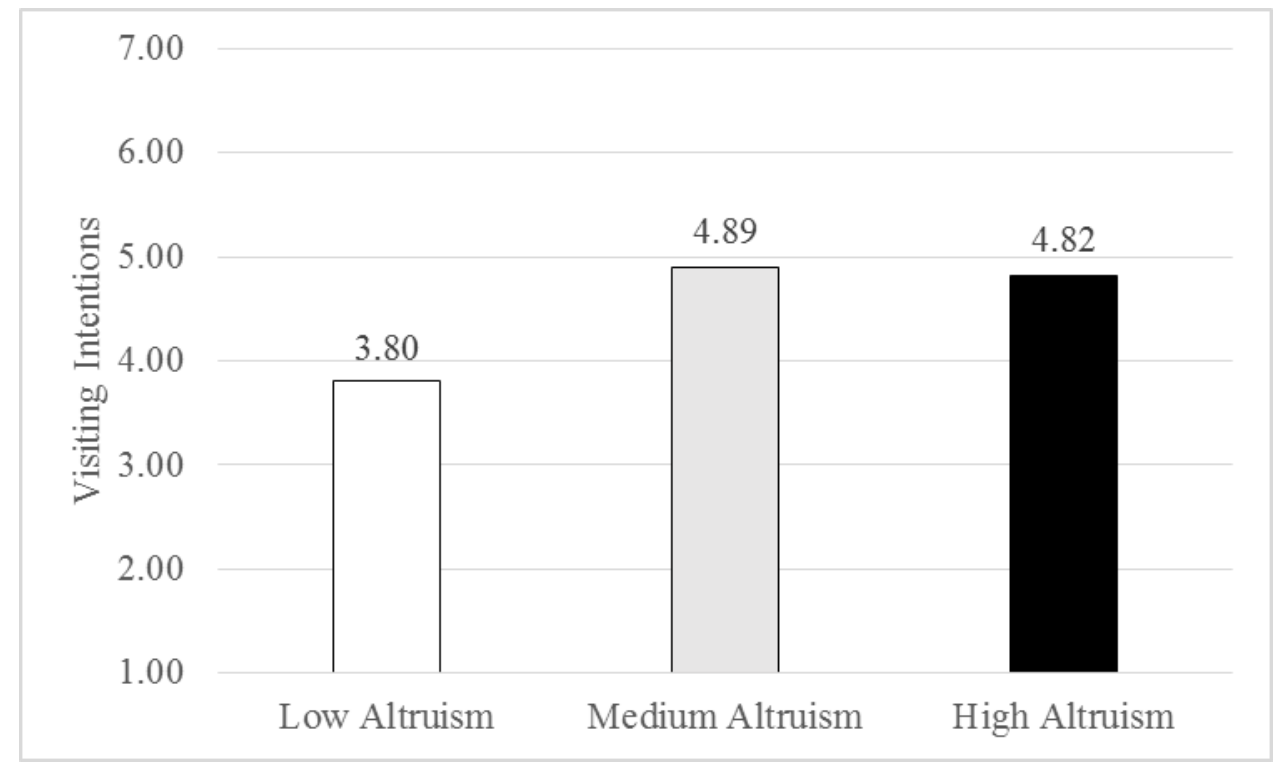


Figure 2 - Mediating effect of authenticity (Study 1)

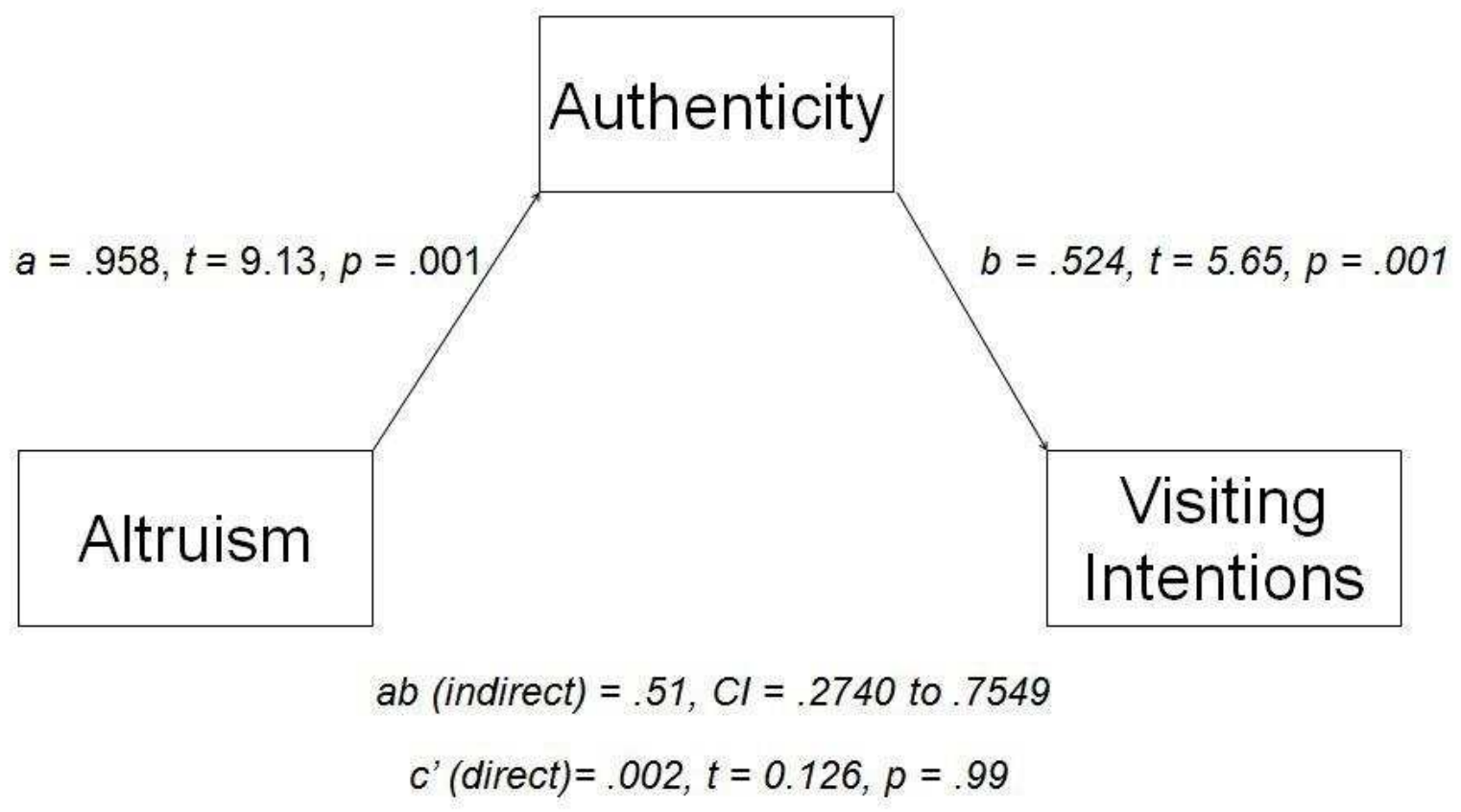


Figure 3- Interaction effect of site's heritage and firm altruism on visiting intentions (Study 2)

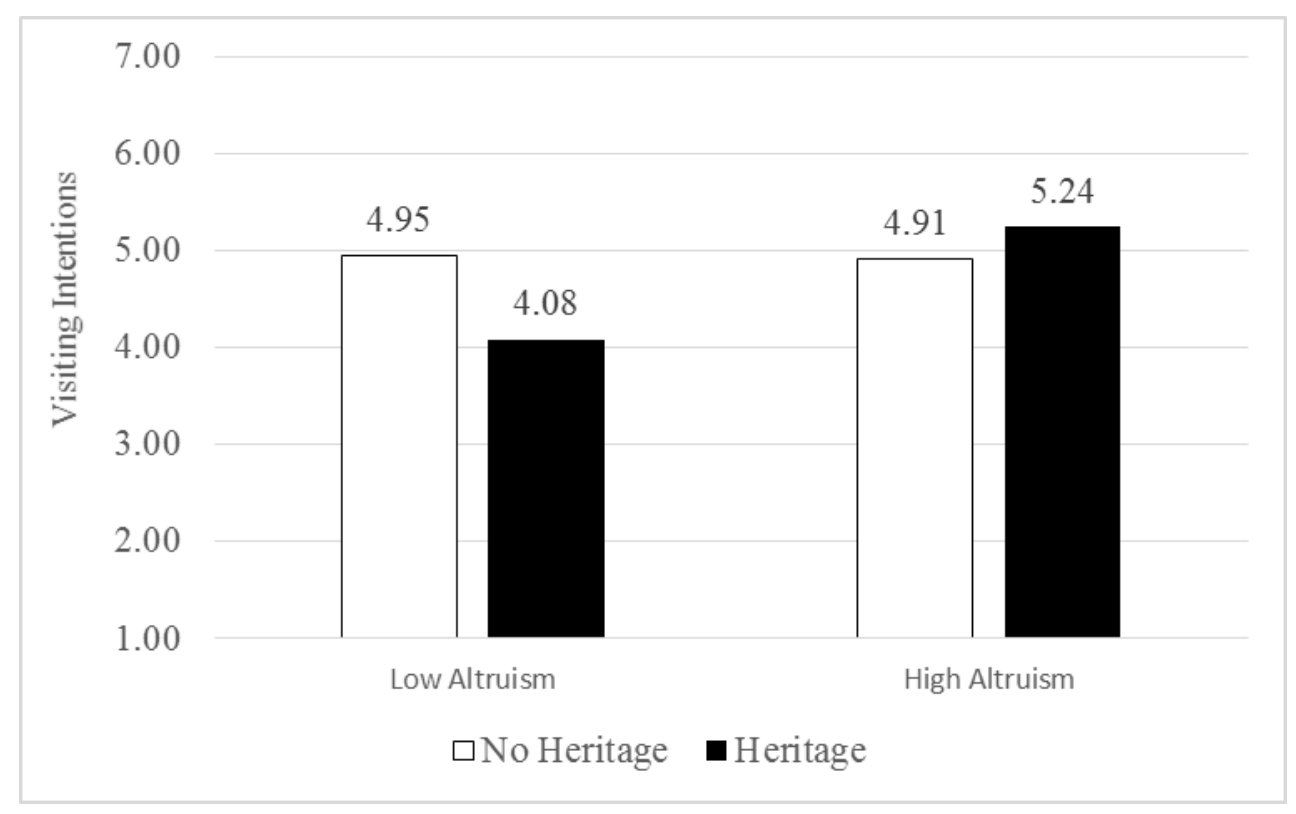


Figure 4 - Moderated Mediation Effect (Study 2)

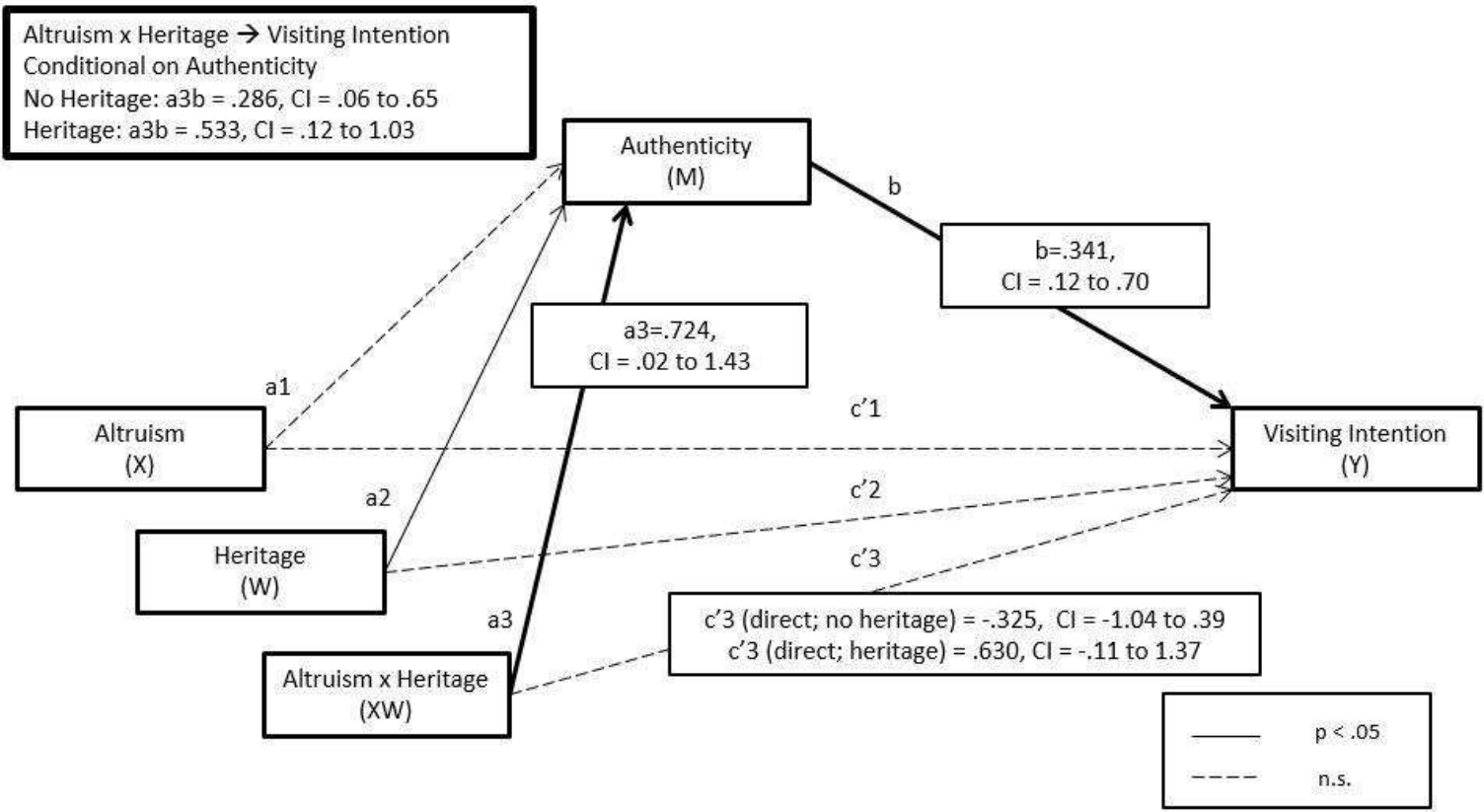

